\title{
Influence of Tetracycline in the Hepatic and Renal Development of Rat's Offspring
}

\author{
Ana Lourdes da Silva Machado*, Adriana Aigotti Haberbeck Brandão, Cláudia Maria de \\ Oliveira Monteiro da Silva and Rosilene Fernandes da Rocha \\ Departament of Biosciencie; Buccal Diagnostic "Julio de Mesquita Filho"; São José dos Campos School \\ of Dentristry; São Paulo State University - UNESP; Av. Engenheiro Francisco José Longo, 777; São Dimas; \\ 12245-000; analour@fosjc.unesp.br; São Josédos Campos - SP - Brasil
}

\begin{abstract}
This study aimed on evaluating the possible effects of tetracycline administered to rats on the tenth day of pregnancy, on kidney and liver development of their offspring. The liver showed vacuolization, necrosis, inflammation and sinusoidal dilatations, more evident in the newborn. Mitosis, early increase of Kupffer cells population and hipertrophy of hepatocytes with greater synthesis of glycogen were present on the tenth and twentieth days of life. The kidney showed slight tubular vacuolizations and necrosis, more proeminent in the newborn, as well as signs of tubular regeneration on the tenth and twentieth days. These results suggested that the organs studied went through several transitory morphological changes during development but presented signs of regeneration along the first days of life.
\end{abstract}

Key words: Pregnancy, Development, Tetracycline, Hepatotoxicity, Nephrotoxicity

\section{INTRODUCTION}

The concern about the use of medication during pregnancy started in the early $60 \mathrm{~s}$ after the thalidomide tragedy in which pregnant women gave birth to children with malformed arms (Schüler et al.,1998; Wannmacher and Ferreira, 1999). During pregnancy many medications are used including antibiotics. Health professionals that prescribe them should be worried not only with the adequate dose for a pregnant woman (Balligan and Hale, 1993) but also and specially with the teratogenic effect thatthose could bring to the fetus (Beckman and Brent, 1984). According to the protocol developed by the Clinical Teratology in the United States the tetracycline are among the antibiotics with high teratogenic risk to humans (Friedman et al.,1990). In the early 60s, researchers observed that the deposition of tetracycline hydrochloride in the skeleton of chicks and birds (Bevelander et al.,1960; Rolle et al.,1962), and rats (Cohlan et al.,1963) resulted in a reduction in the size of the animals. The presence of hepatic vacuolization was observed in fetus of rats that received a few doses at about half of the gestation period (Silva and Rocha, 1995). In offsprings of rats, the presence of fluorescent bands in dentin and enamel, in both the incisors and molars, were evident after the use of the drug (Bevelander et al.,1961; Cohlan et al.,1963). Transient tubular nephropathy with cellular debris and figure of mitosis were also evident (Lindquist and Fellers,1966). The liver of young rats showed, in the initial analysis period, reduction of

\footnotetext{
${ }^{*}$ Author for correspondence
} 
mitochondria, hepatic vacuolization and slight increase of collagen fibers between the hepatocytes and, after 34 days no fat drops could be observed. The fibroblasts were larger in the portal spaces, however (Hagel-Lewicka et al., 1980). Calves that used oxytetracycline showed tubular nephrosis, but did not present hepatocellular degeneration (Alexander et al., 1984). In pregnant rats and guinea-pigs the administration of tetracycline resulted in fatty degeneration of hepatic cells (Steiner et al., 1965; Romert and Matthiessen, 1986) and in adult rats, it caused vacuolar degeneration in both kidney (Hayashi, 1961) and liver (Shauer et al., 1974). In dogs, the microscopic changes were degeneration and tubular necrosis in the kidney (Öbek et al., 1974), and fatty accumulation in the hepatocytes, dose-dependent (Amacher and Martin, 1997). The pathogenicity of the tetracycline is obvious in kidney and liver. Therefore, we decided to evaluate the changes in these organs in rat's offspring after the administration of tetracycline hydrochloride on the $10^{\text {th }}$ day of pregnancy, when the organogenesis is greater.

\section{MATERIALS AND METHODS}

Fifteen female rats, 90 days old, virgins, of Wistar strain (Rattus novergicus, var. albinus), weighting from 200 to $250 \mathrm{~g}$ were used in this study.

After determing the pregnancy according to the methods of Silva and Rocha (1995), the rats were randomly separated into 4 treated groups $(n=3)$ and a control group $(n=3)$. All rats underwent a single dose treatment on the $10^{\text {th }}$ day of pregnancy. The control group rats received 0.5 $\mathrm{ml}$ of sterile physiological solution $(0.9 \% \mathrm{NaCl})$ and the treated rats received tetracycline hydrochloride, diluted in sterile physiological solution $(0.9 \% \mathrm{NaCl})$ intraperitoneally. The first group received $25 \mathrm{mg} / \mathrm{kg}$, the second $50 \mathrm{mg} / \mathrm{kg}$, the third $75 \mathrm{mg} / \mathrm{kg}$ and, the fourth $100 \mathrm{mg} / \mathrm{kg}$. After 21 days the rats were born and two offsprings of each rat were sacrificed at birth, and after 10, 20 and, 30 days of life $(n=6)$. Intramuscular injection of muscular relaxant/ general anestesic solution (xylidine-tiazina hydrochloride/ketamine) in a proportion of $1: 0.5 \mathrm{ml}$ and in a dose of 0.1 $\mathrm{ml} / 100 \mathrm{~g}$, was used for the sacrifice. One of the kidneys and slices of the liver of each animal were removed and fixed in a $10 \%$ formalin solution, embedded in paraffin and sectioned at $5 \mu \mathrm{m}$. The slides were stained with hematoxylin-eosin (HE) and with Periodic Acid Schiff (PAS) and analyzed under light microscopy.

\section{RESULTS}

The livers of newborns in the treated groups presented lesions such as hepatocyte vacuolization, sinusoidal dilatation, foci of necrosis, inflammation and hematopoiesis cells (Fig. 1). These changes were more intense as the tetracycline dose increased. Hepatocyte vacuolization was greater in the newborn. Generally, the vacuoles were small, numerous and not well delimited in the animals whose mother received small tetracycline dose and were large and well delimited when they received higher doses. No glycogen granules were observed in liver newborns. The livers of the offsprings in the treated groups sacrificed with ten, twenty and thirty days of life showed a decrease in the amount of vacuolization and signs of reparation such as the presence of hyperthrophic and very eosinophilic hepatocytes, increased number of mitoses and increased population of Kupffer cells (Fig. 2). Glycogen granules were evident in the ten, twenty, and thirty days-old animals, specially in the hyperthrophic hepatocytes and Kupffer cells of the treated animals. The liver of the control group, 30 days old, showed signs of maturity and no changes. The kidneys of the offsprings of the treated rats showed signs of lesion. It was observed moderate amount of vacuolization in the convoluted tubules and Henle's loop and, foci of necrosis in the tubular epithelium, that increased according to the dose. The offsprings of treated rats with ten and twenty days showed some figures of mitoses in the convoluted tubules and Henle's loop although there were still regions with slight vacuolization and a few necrotic cells in the tubular epithelium (Fig. 3). In the treated offsprings with twenty days, the kidney presented slight vacuolization only when larger doses were administered. The kidneys of the treated offsprings with thirty days of life presented normal aspects. The liver and kidney of all newborns (treated and control) presented immaturity and extra-medullar hematopoiesis. 


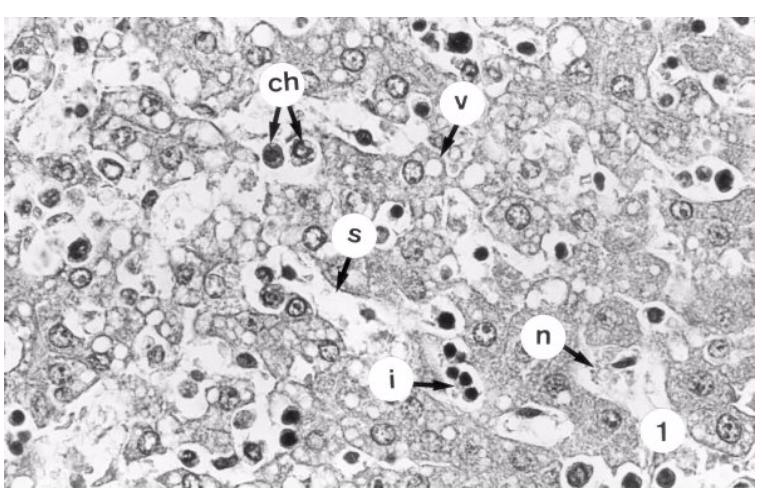

Figure 1- Liver: Newborn - treated - 100mg/Kg vacuolization in the hepatocytes (v), dilated sinusoids (s), focis of necrosis (n), focis of inflammation (i) and focis of hematopoiesis cells (ch). HE 630X

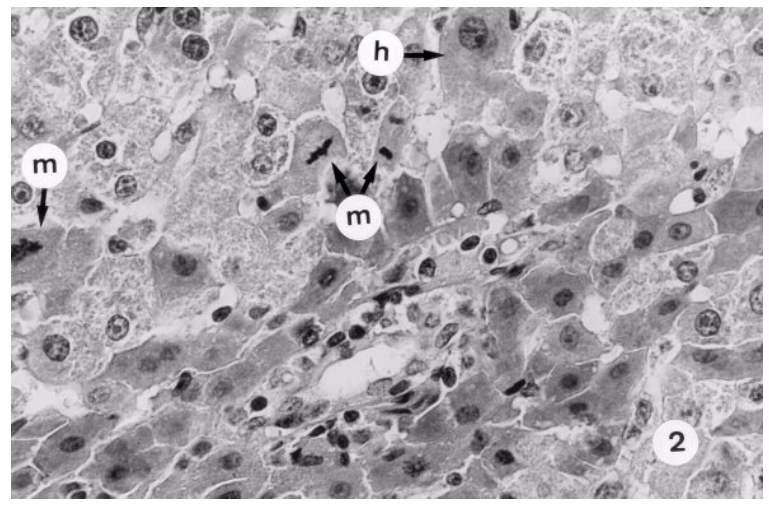

Figure 2 - Liver: 30days - treated - 100mg/Kg hyperthrophic and eosinophilic hepatocytes (h) and mitosis (m). HE 630X

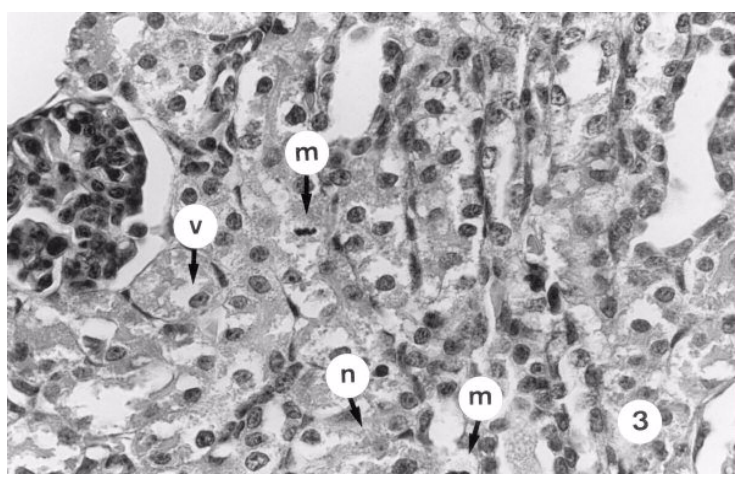

Figure 3 - Kidney: 10days - treated - 100mg/Kg slight vacuolization in the convoluted tubules (v), necrosis (n) and figures of mitosis (m). HE 630X

\section{DISCUSSION}

The prescription and use of antibiotics during pregnancy should be carefully considered because damages to the fetus must be avoided. On the other hand, both the mother and the baby cannot be harmed by inadequate treatment of infections. The tetracyclines are mentioned as being responsible for a number of changes. In our material the most evident tissular changes in the liver were observed in the groups of newborns, specially those that received 50,75 and $100 \mathrm{mg} / \mathrm{kg}$ dose. The hepatocytes showed intense diffuse vacuolization with many small, medium and large vacuoles. This information agreed with the findings of Silva and Rocha (1995). However, Romert and Matthiessen (1986) did not observe increase in vacuolization using larger doses during six days, probably because they used chlortetracycline in guinea pigs. In these studies, the authors also administrated the drug at about half of the gestation period, when the organogenesis was greater. We observed small quantity of vacuolization, mostly small and medium, in the treated animals sacrificed after 10, 20 and 30 days of life. In the study of HagelLewicka et al. (1980), animals treated for a long period presented a single large fatty vacuole in the hepatocytes and more quantity of collagen fiber in the portal spaces, probably due to the continuity of the treatment. In our findings, there was a slight increase in the collagen fibers only in the portal spaces, with no parenchyma distortion. The hypertrophy of the hepatocytes and the occurrence of mitoses, suggesting regeneration, were the most striking characteristics of the animals at ten, twenty and thirty days of age, specially the ones which received 50,75 and $100 \mathrm{mg} / \mathrm{kg}$ doses. Hagel-Lewicka et al. (1980) found many binuclear hepatocytes and moderate quantity of glycogen granules. The increase in glycogen in our material was more evident in the hyperthrophic hepatocytes and Kupffer cells. These macrophages were seen more frequently in the treated animals with 10, 20 and 30 days. Nevertheless, only the newborns and offsprings with 10 days presented necrosis. Shauer et al. (1974) and Amacher and Martin (1997) also used single doses in their experiments and likewise noted the presence of cytoplasm changes such as the formation of fatty vesicles in the hepatocytes after a few hours of observation, suggesting metabolic changes with accumulation of substances after the use of tetracyclines. In the 
kidney of the newborns, we observed dosedependent vacuolization in the convoluted tubules and Henle's loop. Foci of tubular necrosis were more evident in the animals that received 100 $\mathrm{mg} / \mathrm{kg}$ of the drug. Lindquist and Fellers (1966) found similar results in rats and Alexander et al. (1984) in calves. We still found a slight vacuolization was in all young rats with 10 and 20 days of life, with doses of 75 and $100 \mathrm{mg} / \mathrm{kg}$. While we observed a slight increase of mitoses in the kidneys, indicating regeneration of the tubular epithelium, Lindquist and Fellers (1966) found frequent mitosis. It should be pointed out, however, that our experiment was performed on the female rats and with a single dose, while their experiment was prolonged and the offsprings received the medication instead of the pregnant rats. Fromenty and Pessayre (1997) observed that the organelles that changed in the presence of tetracycline were mainly mitochondrias, because it inhibited the beta oxidation enzyme, resulting in an accumulation of triglycerides inside the cytoplasm. The tetracyclines, specially the hydrochloride, the oxytetracycline and doxycycline are commonly used not only in veterinary medicine but also in additives used to feed animals eaten by men. The residues of these substance left in the muscles, liver and kidneys were detected by chromatography (HPLC- High Performance Liquid Chromatograph) (Oka et al., 1991; Croubels et al., 1997; Oka et al., 1997; Posyniak et al., 1998). Concluded that a single dose of tetracycline hydrochloride during pregnancy was enough to cause changes in the liver and kidneys of rat's offsprings, which were dose-dependent. The liver was the organ that suffered the most with the medication. In spite of the changes in liver and kidneys, they were able to regenerate. The period of 30 days was not enough for a complete regeneration of the liver, but the kidney presented normal characteristics after this period.

\section{RESUMO}

O objetivo deste estudo foi avaliar os possíveis efeitos da tetraciclina administrada a ratas, no décimo dia de gestação, no desenvolvimento hepático e renal de seus filhotes. O fígado mostrou vacuolização, necrose, inflamação e dilatação sinusoidal mais evidente em recém-nascidos. Mitoses, aumento precoce da população de células de Kupffer e hipertrofia de hepatócitos com maior síntese de glicogênio estavam presentes no décimo e vigésimo dias de vida. $\mathrm{O}$ rim mostrou vacuolização tubular e necrose discretas, mais evidentes nos recém-nascidos, assim como sinais de regeneração tubular no décimo e vigésimo dias. Esses resultados sugeriram que os órgãos estudados sofreram alterações morfológicas transitórias durante o desenvolvimento, mas apresentaram sinais de regeneração ao longo dos primeiros dias de vida.

\section{REFERENCES}

Alexander, A. F. et al. (1984), Oxytetracyclineassociated nephrotoxicosis in feedlot calves. J. Am. Vet. Med. Assoc., 185, 793-795.

Amacher, D. E. and Martin, B. A. (1997), Tetracycline - induced steatosis in Primary canine hepatocyte cultures. Fundam. Toxicol., 40, 256-263.

Balligan, F. J. and Hale, T. M. (1993), Analgesic and antibiotic administration during pregnancy. Gen. Dent., 41, 220-225.

Beckman, D. A. and Brent, R. L. (1984), Mechanisms of teratogenesis. Ann. Rev. Pharmacol. Toxicol., 24 483-500.

Bevelander, G. et al. (1960), The effect of the tetracycline on the development of the skeletal system of the chick embryo. Dev. Biol., 2, 298-312.

Bevelander, G. et al. (1961), The effect of the administration of tetracycline on the development of teeth. J. Dent. Res., 40, 1020-1024.

Cohlan, S. Q. et al. (1963), Growth inhibition of prematures receiving tetracycline. Am. J. Dis. Child., 105, 65-73.

Croubels, S. M. et al. C.H. (1997), Use of metal chelate affinity chromatography and membrane-based ionexchange as clean-up procedure for trace residue analysis of tetracyclines in animal tissue and egg. J. Chromatog. B, 690, 173-179.

Friedman, J. M. et al. (1990), Potencial human teratogenicity of frequently prescribed drugs. Obstet. Gynecol., 75594-599.

Fromenty, B. and Pessayre, D. (1997), Impaired mitocondrial function in microvesicular steatosis: effects of drugs, ethanol, hormones and cytokines. J. Hepatol., 26, 43-53.

Hagel-Lewicka, E. et al. (1980), Ultrastructural investigations of the liver in young (suckling) rats receiving tetracycline hidrocloride. Mat. Med. Pol., 4, 259-262.

Hayashi, K. (1961), Experimental studies on histopathological changes in the liver and kidney of rats following antibiotics administration. J. Exp. Med., 8, 156-162. 
Lindquist, R. R. and Fellers, F. X. (1966), Degraded tetracycline nephropathy: functional, morphologic and histochemical observations. Lab. Invest., 15, 864-876.

Öbek, A. et al. (1974), Effects of tetracycline on the dog kidney: a functional and ultrastructural study. Isr. J. Med. Sci., 10, 765-771.

Oka, H. et al. (1991), Limited survey of residual tetracyclines in tissues collected from diseased animals in Aichi prefecture, Japan. J. Assoc. Off. Anal. Chem., 74894-896.

Oka, H. et al. (1997), Improvement of chemical analysis of antibiotics XXIII ${ }^{1}$. Identification of residual tetracyclines in bovine tissue by electrospray high-performance liquid chromatography-tandem mass spectrometry. J. Chromatogr. B, 693, 337-344.

Posyniak, A. et al. (1998), Determination of tetracycline residues in animal tissues by liquid chromatography. Biomed. Chromatogr., 12 294-299.

Rolle, G. K. et al. (1962), Appearance and persistence of tetracycline: induced fluorescence in the bones of embryonic and growing chicks. Am. J. Vet. Res., 23, 315-319.

Romert, P. and Matthiessen, M. E. (1986), Tetracycline-induced oranges in hepatocytes of minipigs and mini-pigs foetuses as revealed by electron microscopy. Acta Pathol. Microbiol. Immunol. Scand. Sect. A, 9,4125-131.
Schüler, L. et al. (1998), Fármacos e gestação In: Farmacologia clínica: fundamentos da terapêutica racional.ed. Guanabara Koogan, Rio de Janeiro. pp. 602-608.

Shauer, B. A. et al. (1974), Biochemical indices of tetracycline hepatic injury in rats. Proc. Soc. Exp. Biol. Med., 147, 868-872.

Silva, J. R. O. and Rocha, R. F. (1995), Efeitos do cloridrato de tetraciclina em fetos de ratas tratadas com o antibiótico. Rev. Odontol. UNESP, 24, 109-115.

Steiner, G. et al. (1965), Tetracycline-induced abortion in the rat. Labor. Invest., 14, 1456-1463.

Wannmacher, L. and Ferreira, M. B. C. (1999), Uso de fármacos durante a gestação e lactação,. In: Farmacologia clínica para dentistas, ed. Guanabara Koogan, Rio de Janeiro. pp. 270-273.

Received: October 10, 2001; Revised: February 19, 2002; Accepted: July 09, 2002. 


\title{
PÁGINA
}

\author{
EM
}

BRANCO 